\title{
Working towards internationalization through the top management leadership skills and faculty research ca- pability: A convergent parallel design
}

\author{
Jihan A. Labrador ${ }^{1^{*}}$, Thelma O. Alderite ${ }^{2}$ \\ 1, 2 University of the Immaculate Conception, Davao City, Phillipines
}

\author{
Keywords \\ Educational leadership \\ Internationalization status \\ Faculty research capability \\ Top management \\ Leadership skills \\ Convergent parallel \\ Design \\ Philippines
}

Received: 27 July 2020

Accepted: 15 October 2020

Published: 15 December 2020

\begin{abstract}
The study endeavored to explore the institutional internationalization efforts through the top management leadership skills and faculty research capability among the State Universities and Colleges (SUCs) in Region XI. The quantitative component made use of survey questionnaires administered to 400 participants. The method used was descriptive, correlational, and multi-regression analysis as it delved to test the theory of leadership skills among the SUCs heads, faculty research capability, and their relationship to institutional internationalization efforts. There were 10 participants involved in the in-depth interview and seven informants for focus group discussion to examine their lived experiences as they engaged in research, their experiences with the leadership of their heads, and how these experiences shaped their attitudes, commitment, and aspirations concerning institutional internationalization efforts. A triangulation mixed-method design was used to compare and corroborate the results. Findings had shown that top management leadership skills and faculty research capability influenced the institutional internationalization efforts among SUCs in Region XI. Future studies may venture into the influence of emerging variables from qualitative findings. This includes variables like innovative leadership and creative services.
\end{abstract}

(c) 2020 The Author(s). Published by TAF Publishing.

\section{INTRODUCTION}

\section{Background of the Study}

Internationalization as the key player in the educational system in this new era had pressured so much the Higher Education Institutions (HEIs) to cope with the external environment. It is the force acting in educational institutions that is tied to culture, economy, politics, business, and power. The need for critical attention for research in order to generate knowledge and discover new strategies is necessary in improving the quality of human life. All faculty members are encouraged to engage in quality research, and support from the administration is very much desired (Commission on Higer Education, 2016). Meanwhile, HEIs have developed approaches in response to this growing globalized population while internationalization was regarded by experts to be the prompt action of the HEIs to these phenomena (Dimasindel \& Salam, 2018).

While internationalization of higher education is the process of change where each individual aims to achieve the interest and needs of the higher education (Altbach \& Knight, 2007; Mughal, Ross, \& Fearon, 2017), Republic Act 7722, otherwise known as the Commission on Higher Education mandates HEIs like the SUCs to respond to the call for societal transformation in order to help the struggling colleges and universities to reach the global status.

The Philippine HEIs under the guidance of Commission on Higher Education (CHED) are compelled to adhere to the policies and mandates leading towards the improvement of research productivity.

Based on the research conducted in Universiti Teknologi MARA (UiTM) Malaysia by Nordin (2012), there are many factors that contributed to the effectiveness in implement-

${ }^{*}$ corresponding author: Jihan A. Labrador

†email: jihanlabrador@gmail.com 
ing organizational change. The need to adopt changes required commitment, leadership styles, and emotional distress of the employees in order to implement such change. Thus, the study was intended to determine the influence of leadership behavior and organizational commitment on organizational readiness for change in a learning institution. The study also implied that building organizational commitment as well as developing transformational and transactional leadership behavior could contribute to the formulation of organizational readiness for change and subsequently lead to the success of a change in the organization. In the Philippines, the faculty members of De La Salle University in Manila responded to the call for developing a research culture in the higher education institutions in the Philippines. Forty faculty members from 14 universities and colleges in the country responded to a survey questionnaire and 10 were interviewed with an open-ended question. They found out that the faculty members did not consider any of the indicators of research culture in their respective institutions as being strong. They deemed the indicators of research culture as present only to a moderate extent: impact of research, administrative practice, inter-institutional collaboration, institutional research strategy, financial reward system, infrastructure, the presence of ethical policies, and the availability of research finding (Almonte-Acosta, 2007; Kolodziejczak, Szarska, \& Edelmuller, 2019). They also added that the faculty perceived the factors necessary for improving research productivity includes: time, strong belief in research endeavor, faculty involvement, positive group climate, working conditions and organizational communication, decentralized research policy, research funding, and clear institutional policy for research benefits and incentives.

Christensen and Eyring (2011) and Selingo (2013) stated that HEIs were challenged under increasing pressure to adapt to evolving competitiveness and financial pressure as it changes its institutional revenues just to cope with institutional priorities. It is undeniable that SUCs in the developed world possess a firm tradition of research. They recognized research as an important part of their responsibilities where faculty members of the HEIs have consistently evidenced research productivity together with other factors that contributed to the process. However, SUCs in the developing world have retained strong teaching functions but weak research function (Ozyurek, 2016; Sanyal \& Varghese, 2006). The researcher believed that it is one of the determining factors in any institutional success especially in the HEIs where the productivity of all successful organizations lies on how leaders push their working force to perform at their best.

According to Aschalew Durie and Beshir (2016), effective leadership is central to an organization's success. These are the key constants in leadership regardless of contexts. However, the emphasis and weight may differ but according to Sathye (2004), leadership in academic institutions is more diverse and complex than leadership in other public and private sectors.

In the Philippines, the government had recognized the need for the internationalization of the educational system. The Commission on Higher Education has risen to give support to significant researches on this innovative change considering the HEIs operating in the country. They also ordered all HEIs to enhance the quality of teaching and formulate necessary mechanism ensuring that the graduate can deal with the competitive nature in the global arena (Commission on Higher Education, 2012). Despite of these initiatives, education in the Philippines is still facing perennial problems such as substandard quality, insufficient budget, incompetent faculty researchers, lack of teaching staff, poor facilities, and poor understanding of vision and direction. These are the reasons why Philippines ranked among the low performing countries with limited adaptation of international education system.

Moreover, the limited linkages of SUCs with foreign universities and industries limit its participation in more research activities, which require SUCs more assistance in referrals and procedures on how to participate. In addition, SUCs faculty members particularly the younger faculty members have a low experience in research and development, especially in competitive research which is needed in reaching global status (Japan International Cooperation Agency, 2015).

\section{Objectives}

This study aimed to determine the institutional internationalization efforts through the top management leadership skills and faculty research capability in the SUCs in Davao Region. In particular, this study aimed to:

1. know the status of the leadership skills of the SUCs heads and the faculty research capability of the institution as assessed by the participants.

2. know the extent of the institutional internationalization efforts of the SUCs as assessed by the faculty.

3. determine how leadership skills and faculty research capability significantly predict the institutional internationalization efforts of the SUCs.

4. gather the lived experiences of the participants as they engage in a research for institutional internationalization 
efforts.

5. What are the experiences of teachers on the leadership of their heads among the factors that contributed institutional internationalization efforts?

6. How do these experiences shape the attitudes, commitment, and aspirations of the participants with respect to institutional internationalization efforts?

7. To what extent do the qualitative data corroborate with the quantitative data?

\section{Worldview and Theoretical Lens}

As a pragmatist, the researcher considered the thought as an instrument or tool for prediction, problem solving and action, and reject the idea that the function of thought is to describe, represent, or mirror reality. Pragmatists (Rosenthal, 1987) contend that most philosophical topics such as the nature of knowledge, language, concepts, meaning, belief, and science are all best viewed in terms of their practical uses and successes.

Pragmatism (Rosenthal, 1987) requires appropriate anal-

Independent Variables

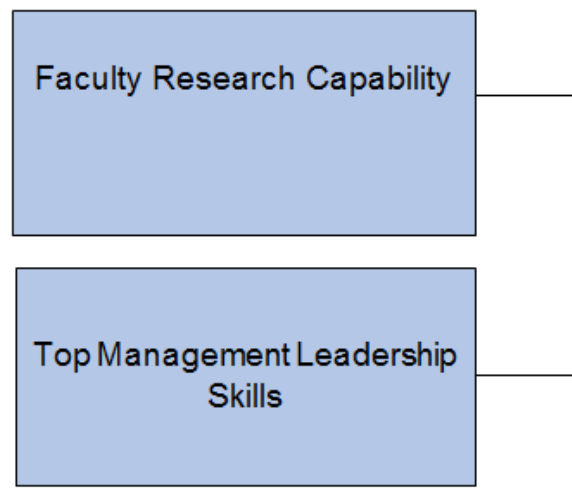

FIGURE 1. Conceptual framework

\section{Research Questions}

This study aimed to determine the institutional internationalization efforts through the top management leadership skills and faculty research capability in the SUCs in Davao Region. In particular, this study aimed to answer the following questions:

1. What is the status of the leadership skills of the SUCs heads and the faculty research capability of the institution as assessed by the participants?

2. What is the extent of the institutional internationalization efforts of the SUCs as assessed by the faculty?

3. Do leadership skills and faculty research capability significantly predict the institutional internationalization efforts of the SUCs?

4. What are the lived experiences of the participants as they engage in a research for institutional internationalization ysis of problems existing in any organization. The ability of the educational institution to respond to varied intricacies depends primarily on the performance of the management team. Leaders in the top management must possess appropriate knowledge and skills in order to be credible and influential in the manner of leading their subordinates to create significant transformation to the whole organization, and to elevate the academic institution's performance to the fullest. Thus, it is essential for a leader to update and tailor his leadership skills so he can fit to the vital needs of all faculty members as human resources in the organization. Moreover, Abraham Maslow's Hierarchy of Needs Theory stated that humans have five sets of need that are arranged in hierarchy. He contends that people start by trying to satisfy their most basic or compelling needs and progress toward the most fulfilling. In order to enhance organizational performance, it is important that the organization recognizes the individual needs of its human resources and provide them opportunities for professional satisfaction.

\section{Dependent Variable}

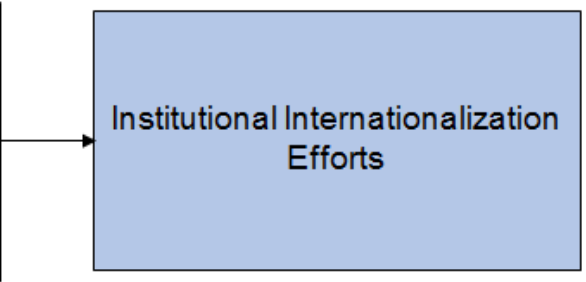

efforts?

5. What are the experiences of teachers on the leadership of their heads among the factors that contributed institutional internationalization efforts?

6. How do these experiences shape the attitudes, commitment, and aspirations of the participants with respect to institutional internationalization efforts?

7. To what extent do the qualitative data corroborate with the quantitative data?

\section{LITERATURE REVIEW}

This section presents the review of related literature and researches on the variables of the study which include institutional internationalization efforts with its indicators: articulated commitment, academic offerings, organizational infrastructure, external funding, institutional investment in 
faculty, and student programs.

\section{Leadership Skills}

For the past decades, there is a paradigm shift from management to leadership. While leadership may have varied definition to different people and to different situations, most people involve in managing organizations see leadership as a dynamic relationship between an individual and members of a group of a specific environment. According to Weathersby (1999) leadership is focused on creating a common vision and motivating people to contribute meaningfully to the attainment of the vision and encouraging them to align their self-interest with that of the organization; it is persuading and not commanding. Leadership is a process that encompasses the behavior of the leader, the behavior of the followers, and the environment of the situation.

\section{Administrative or technical skills}

These skills are related to an individual's specific area of expertise. It implies an understanding of, and proficiency in, a specific kind of activity, particularly one involving methods, processes, or techniques. It is relatively easy for us to visualize the technical skills of a school administrator when he is performing his own special function. It involves specialize knowledge, analytical ability within that specialty, and facility in use of the tools and techniques of the specific discipline (Katz, 2009).

\section{Human or interpersonal skills}

These skills are related to an individual's ability to effectively interact with others. These are the skills that could make some individuals to be a great team member while the others can be terrible. These are the skills that allow some people to succeed as managers and others to fail. As technical skill is primarily concerned with working with "things", such as processes or physical objects, however, human skill is primarily concerned with working with people.

The person with highly developed human skill is aware of his own attitudes, assumptions, and beliefs about other individuals and groups; he is able to see the usefulness and limitations of these feelings Robert Katz's "Skills of an Effective Administrator" in 1955.

\section{Conceptual skills}

As used here, conceptual skill involves the ability to see the enterprise as a whole; it includes recognizing how the various functions of the organization depend on one another, and how changes in any one part affect all the others; and it extends to visualizing the relationship of the individual business to the industry, the community, and the political, social, and economic forces of the nation as a whole. Recognizing these relationships and perceiving the significant elements in any situation, the administrator should then be able to act in a way which advances the over-all welfare of the total organization Robert Katz's "Skills of an Effective Administrator" in 1955.

\section{Faculty Research Capability Computational skills}

Along computational skills, it is stressed on the competence of the researchers in determining their capabilities to use statistical tools or packages or software to analyze data. This implied that researchers shall pursue or undergo trainings and seminars that will enhance their capability in statistics (Jonathan, 2016).

\section{Conceptual skills}

On the level of conceptual skills of the researcher, (Jonathan, 2016) further stated that researcher shall continue conducting researches to strengthen their research skills along this dimension. Their competence in identifying instructional problems in school, determining the boundaries of the study, formulating specific findings of the study, defining and checking research title, formulating specific subproblems, drawing conclusions, and formulating testable hypothesis, are indeed very important.

\section{Technical skills}

Researchers' capability on technical skills is very essential. As a researcher, the ability to use computer for encoding, observing mechanics in thesis writing, observing research formats, documenting the cited literatures correctly, and writing bibliography are but necessary skills for a faculty that needs to be develop. On the other hand, the ability to handle properly the data as well as the use of computer in statistical analysis is also included (Jonathan, 2016).

For developing research culture, several strategies are aimed on improving base on standard model: cluster hiring, revision of institutional policies and infrastructure, and systematic prioritization of research for administrator and for individual faculty members (Huenneke, Stearns, Martinez, \& Laurila, 2017).

The strategy of developing research in cluster areas has demonstrated advantages for emerging research universities (Brix, Svavarsson, \& Leese, n.d.).

However, achievements at the University of Puerto Rico had shown how developmental funding triggers change to promote research in an undergraduate minority-serving institution (Godreau, 2015). Likewise, building research capacity in an emerging research institution also requires assess- 
ment of research management practices and identification of transitional practices to promote the evolving research agenda (Huenneke et al., 2017).

According to Bosch and Taylor (2011), early phrases are marked by hand holding management, institutional emphasis on teaching, a faculty mindset that research is intimidating, and centralized research mission with deans' focus on teaching output and research activity rather than research quality and outcomes. Transition through a broadening phase to the honing phase is marked by increased emphasis on research relative to teaching, decentralization of the research mission into college and department priorities, increase collaborations, and a growing focus on recruitment of high-quality researchers and post graduate students.

\section{Institutional Internationalization Efforts}

Research conducted in Southern Philippines on readiness for internationalization of higher education system shows that HEIs is ready in terms of mission, goal, and plan. In the area of foundation as reflected in their strategic plans and goals, their internationalization policies of the institutions, were articulated as part of their basic policies which have concreteness (Dimasindel \& Salam, 2018).

Moreover, HEIs should be ready in their plans and administrative policies as implementing bodies in order for their goals and plans to be recognized and be shared internationally by their partner schools. Also, an authorized person is important to take charge of the international exchange activities such as exchange of students, exchange of faculty, and collaboration of research, and etc., who will act independently from the college president so that readiness of the HEIs have concreteness of goals in the area of publication (Dimasindel \& Salam, 2018). The HEIs must be committed in embracing the challenges of the internationalization of educational system in the Philippines, and must respond on the rapidly changing globalized world that the CHED described to be an era of global competitiveness.

On the other hand, one of the perennial problems in terms of internationalization is the lack of financial support or budget. According to Dimasindel and Salam (2018) on their research for readiness of HEIs in Southern Philippines in terms of internationalization of higher education system, that allotment for the program was not being prioritized by the HEIs. It further implies that the budget meetings and financial targets were also not done frequently. This perhaps is due to their insufficient allotment for the projects, time for budgeting meetings, and financial targets. Henceforth, providing an idea that the budget for internationalization is not entirely secured that might affect the readiness of HEIs.
Internationalization of higher education is the process of integrating an international or intercultural dimension into the teaching, research, and service functions of the institution. This definition understands internationalization as a process, as a response to globalization, and as including both international and local elements (Knight, 2008). According to Altbach and Knight (2007), internationalization has more to do with the specific policies and programs undertaken by governments, academic systems and institutions, and even individual departments to deal with globalization.

Shenton (2004) have identified generic activities associated with internationalization as follows: international movement of students and staff between countries; internationalization of higher education curricula; international links for research and open learning programs; and bilateral, regional, and international recognition of higher education qualifications.

Internationalization of HEIs is said to have the following benefits: First is that it has a cultural and social impact to the local, regional, and national communities. Second, the movement of students and staffs among campuses allowed them to have new standpoints and help them realize that cooperation among HEIs could be possible. Students and teachers who were sent to scholarships and partnership activities would have the possibility of acquiring new knowledge and could possibly give them international opportunities. Third, is that internationalization becomes an avenue for HEIs to establish a mechanism which will promote quality assurance and enhancement of both academic and administrative processes conforming to international quality standards (Bordean \& Borza, 2013).

Internationalization of HEIs becomes a subject of interest by several academic institutions as policymakers and institutional administrators are now paying attention to this phenomenon because economic performance is affected by the growing cross-border flows of knowledge, knowledge-workers, and students (Organisation for Economic Co-operation and Development, 2008; Pama, 2015).

\section{RESEARCH METHODOLOGY}

\section{Research Design}

This study utilized a convergent parallel design, a mixed method approach. This research design involves collecting, analyzing, and integrating quantitative and qualitative research in a single study or a longitudinal program of inquiry. The purpose of this kind of research is that both quantitative and qualitative research, in combination, provide a better understanding in a research problem or issue than either 
research approach is alone (Creswell \& Poth, 2016). Additionally, this method was used to confirm, cross-validate or corroborate findings. Hence, it is often used to overcome

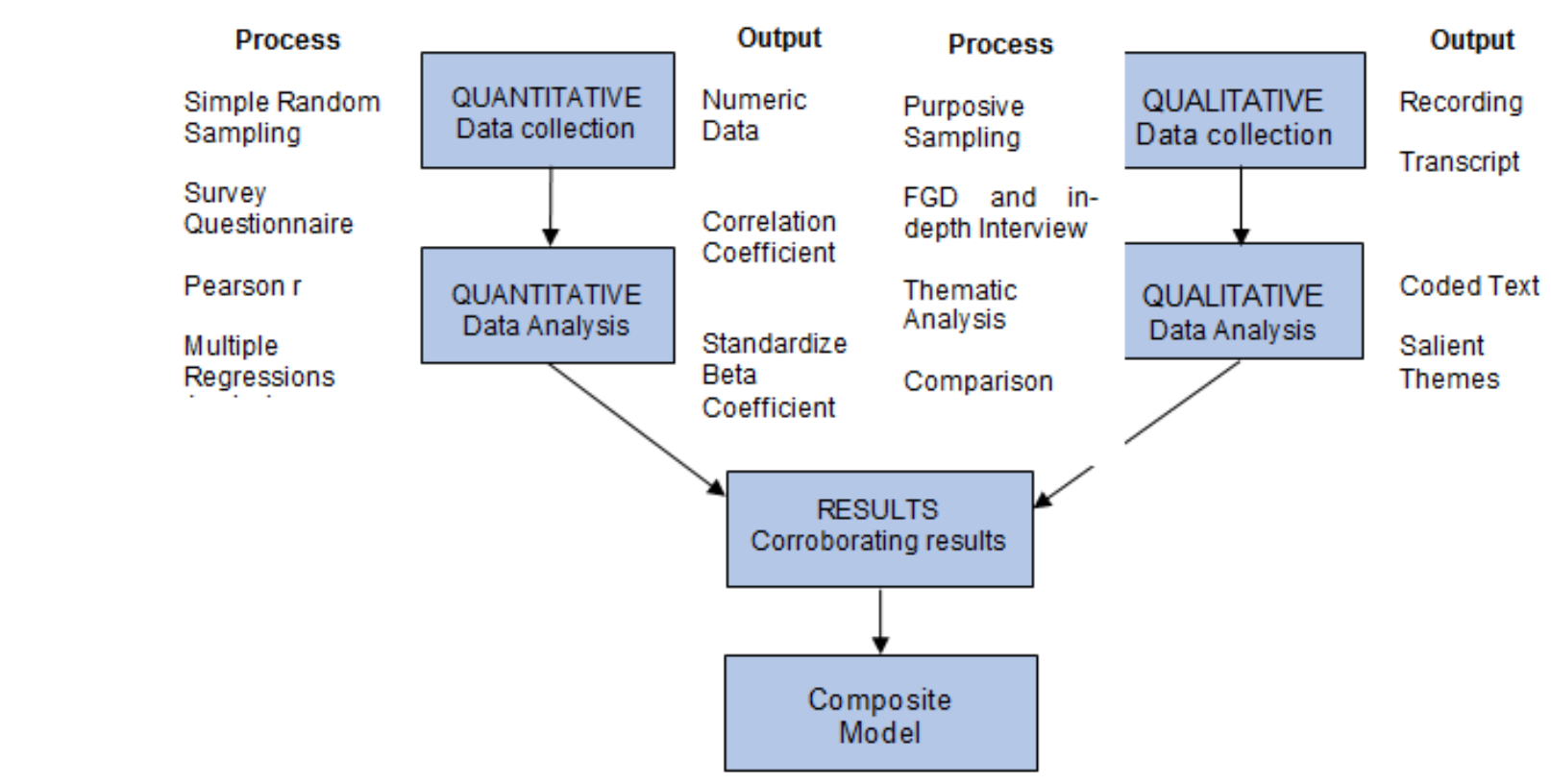

a weakness in one method with the strengths of another (Creswell \& Poth, 2016).

FIGURE 2. Figure of procedures

\section{RESULTS}

Table 1 had shown the status of top management leadership skills in the five State Universities and Colleges in Region XI had obtained an overall mean value of 4.02 with a descriptive equivalent level of high which implies that leadership skills were oftentimes evident among SUCs in Region XI.

TABLE 1. Status of the top management leadership skills in SUCs in region XI

\begin{tabular}{|c|c|c|c|}
\hline Category Mean & Mean & Std. Deviation & Descriptive Level \\
\hline \multicolumn{4}{|l|}{ Administrative Skills } \\
\hline 1. Being effective with the detailed aspects of their work & 4.08 & .71 & High \\
\hline 4. Filling up forms and working with details comes easily for me & 4.04 & .77 & High \\
\hline 7. Having the strength in managing people and resources & 4.01 & .85 & High \\
\hline 10. Enjoying responding to people's request and concern at work & 3.97 & .84 & High \\
\hline 13. Obtaining and allocates resources is a challenging aspect of their job & 4.06 & .80 & High \\
\hline $\begin{array}{l}\text { 16. Being effective at obtaining resources to support our programs } \\
\text { Interpersonal Skills }\end{array}$ & 4.06 & .83 & High \\
\hline 2. Knowing ahead of time how people will respond to a new idea or proposal & 4.01 & .79 & High \\
\hline 5.Understanding social fabric of the organization is important & 4.04 & .80 & High \\
\hline 8. Having able to sense the emotional undercurrent in my group & 3.86 & .84 & High \\
\hline 11. Using my emotional energy to motivate others & 3.92 & .82 & High \\
\hline 14. Respecting the key to successful conflict resolution on their opponent & 4.06 & .80 & High \\
\hline 17. Working hard to find consensus in conflict resolutions & 4.08 & .76 & High \\
\hline \multicolumn{4}{|l|}{ Conceptual Skills } \\
\hline 3. Being effective at problem solving & 4.01 & .74 & High \\
\hline 6. Addressing immediately the problem when they arise & 4.04 & .84 & High \\
\hline 9. Seeing the big picture comes easily for them & 3.93 & .83 & High \\
\hline 12. Making strategic plans for the company & 4.14 & .76 & High \\
\hline 15. Enjoying discussing organizational values and philosophy & 4.06 & .82 & High \\
\hline 18. Being flexible about making changes in the organization & 4.07 & .82 & High \\
\hline Category Mean & 4.04 & .70 & High \\
\hline Overall Mean & 4.02 & .68 & High \\
\hline
\end{tabular}


TABLE 2. Status of the faculty research capability in SUCs in Region XI

\begin{tabular}{|c|c|c|c|}
\hline Category Mean & Mean & Std. Deviation & Descriptive Level \\
\hline \multicolumn{4}{|l|}{ Computational Skills } \\
\hline $\begin{array}{l}\text { 1. Identifying appropriate statistical tools to determine the extent of relia- } \\
\text { bility of the instrument. }\end{array}$ & 4.30 & .77 & Very High \\
\hline 2. Interpreting the reliability of coefficient in dry-run of the instrument & 4.17 & .81 & High \\
\hline 3. Establishing suited measuring scale in the data gathering tool. & 4.26 & .78 & Very High \\
\hline $\begin{array}{l}\text { 4. Determining appropriate statistical tools for univariate, bivariate and } \\
\text { multivariate problems. }\end{array}$ & 4.16 & .79 & High \\
\hline $\begin{array}{l}\text { 5. Computing and interpreting the statistical data for a univariate problem } \\
\text { like frequency count, percentage, ranking and mean values. }\end{array}$ & 4.25 & .78 & Very High \\
\hline $\begin{array}{l}\text { 6. Computing and interpreting the bivariate and multivariate data like re- } \\
\text { lationship or differences of the variables consider. }\end{array}$ & 4.17 & .76 & High \\
\hline 7. Knowing the tabular presentation of data. & 4.28 & .76 & Very High \\
\hline 8. Know data processing of problems on relationships or differences. & 4.28 & .71 & Very High \\
\hline 9. Locating the critical values. & 4.22 & .79 & Very High \\
\hline 10. Interpreting the level of significance used in the study. & 4.31 & .78 & Very High \\
\hline 11. Using the Computer (SPSS) or other statistical software to analyze data. & 4.07 & .86 & High \\
\hline Category Mean & 4.22 & .65 & Very High \\
\hline \multicolumn{4}{|l|}{ Conceptual Skills } \\
\hline 1. Identifying instructional problems in the school. & 4.26 & .71 & Very High \\
\hline 2. Transforming instructional problems into a good research problem. & 4.15 & .72 & High \\
\hline 3. Defining and checking carefully the research title. & 4.33 & .69 & Very High \\
\hline $\begin{array}{l}\text { 4. Formulating the conceptual framework of the study based on the objec- } \\
\text { tives. }\end{array}$ & 4.33 & .73 & Very High \\
\hline 5. Formulating specific sub-problems. & 4.22 & .71 & Very High \\
\hline 6. Formulating testable hypothesis. & 4.29 & .73 & Very High \\
\hline 7. Determining the boundaries of the study. & 4.29 & .72 & Very High \\
\hline 8. Defining terms operationally and conceptually. & 4.31 & .75 & Very High \\
\hline 9. Establishing relevance of the study. & 4.38 & .69 & Very High \\
\hline 10. Preparing review of literature objectively. & 4.34 & .69 & Very High \\
\hline 11. Determining research design to be used. & 4.32 & .74 & Very High \\
\hline $\begin{array}{l}\text { 12. Arranging research setting, respondents and spell out the procedures } \\
\text { and conditions. }\end{array}$ & 4.27 & .72 & Very High \\
\hline 13. Preparing data gathering tools of the study. & 4.32 & .75 & Very High \\
\hline 14. Analyzing and interpreting the outcome of the study. & 4.34 & .72 & Very High \\
\hline 15. Formulating the specific findings of the study. & 4.32 & .74 & Very High \\
\hline 16. Drawing conclusions accurately. & 4.31 & .73 & Very High \\
\hline 17. Drawing recommendations properly. & 4.32 & .74 & Very High \\
\hline 18. Prioritizing instructional problems. & 4.21 & .77 & Very High \\
\hline Category Mean & 4.29 & .59 & Very High \\
\hline \multicolumn{4}{|l|}{ Technical Skills } \\
\hline 1. Handling data correctly & 4.43 & .70 & Very High \\
\hline 2. Encoding the study using the computer. & 4.39 & .71 & Very High \\
\hline 3. Observing the mechanics of thesis/dissertation writing. & 4.32 & .73 & Very High \\
\hline 4. Observing the research format. & 4.33 & .73 & Very High \\
\hline 5. Writing bibliography properly. & 4.29 & .72 & Very High \\
\hline 6. Documenting the cited literatures correctly. & 4.37 & .70 & Very High \\
\hline 7. Using the computer in statistical analysis. & 4.24 & .83 & Very High \\
\hline Category Mean & 4.34 & .61 & Very High \\
\hline Overall Mean & 4.28 & .56 & Very High \\
\hline
\end{tabular}


Faculty Research Capability. Moreover, Table 2 shows that the status of faculty research capability in the five State Universities and Colleges in Region XI had obtained an overall mean of 4.28 with a descriptive equivalent level of very high which implies that faculty research capability is oftentimes evident in the SUCs in Region XI. Also, the overall SD is .56 which denotes that the responses of respondent are more or less clustered to the mean.

Table 3 presents the status of institutional internationalization efforts in the four SUCs in Region XI where this variable had obtained an overall mean value of 3.72 with a descriptive equivalent level of high which means that institutional internationalization efforts was oftentimes observed among the SUCs in Region XI.

TABLE 3. Extent of institutional internationalization efforts of the state universities and colleges in region XI

\begin{tabular}{|c|c|c|c|}
\hline Category Mean & Mean & Std. Deviation & Descriptive Level \\
\hline \multicolumn{4}{|l|}{ Articulated Commitment } \\
\hline $\begin{array}{l}\text { 1. Conducting formal assessment of internationalization in the last three } \\
\text { years }\end{array}$ & 3.82 & .91 & High \\
\hline 2. Highlighting international education in recruitment literature & 3.81 & .85 & High \\
\hline $\begin{array}{l}\text { 3. Creating policies to enable students to study abroad without delaying } \\
\text { graduation }\end{array}$ & 3.77 & .96 & High \\
\hline Category mean & 3.80 & .80 & High \\
\hline \multicolumn{4}{|l|}{ Academic Offerings } \\
\hline 4. Administering international internships for credit & 3.65 & 1.04 & High \\
\hline 5. Administering international field study for credit & 3.62 & 1.00 & High \\
\hline Category mean & 3.64 & 1.01 & High \\
\hline \multicolumn{4}{|l|}{ Organizational Infrastructure } \\
\hline $\begin{array}{l}\text { 6. Creating a campus-wide task force exclusively for international educa- } \\
\text { tion }\end{array}$ & 3.59 & .99 & High \\
\hline 7. Using internal e-mail to communicate about international education & 3.75 & .94 & High \\
\hline $\begin{array}{l}\text { 8. Using an established system to communicate about students' study } \\
\text { abroad experiences. }\end{array}$ & 3.68 & .95 & High \\
\hline Category mean & 3.67 & .88 & High \\
\hline \multicolumn{4}{|l|}{ External Funding } \\
\hline 9. Seeking actively funding for international education & 3.70 & 1.10 & High \\
\hline 10. Receiving funding from other NGOs & 3.80 & .96 & High \\
\hline 11. Receiving funding from other Government Agencies & 3.90 & .91 & High \\
\hline Category mean & 3.80 & .86 & High \\
\hline \multicolumn{4}{|l|}{ Institutional Investment in Faculty } \\
\hline 12. Earmarking funds for faculty to lead study abroad programs & 3.82 & .96 & High \\
\hline $\begin{array}{l}\text { 13. Earmarking funds for faculty to travel abroad for meetings and confer- } \\
\text { ences }\end{array}$ & 3.80 & .93 & High \\
\hline 14. Earmarking funds for faculty to study or conduct research abroad & 3.73 & 1.00 & High \\
\hline Category mean & 3.78 & .910 & High \\
\hline \multicolumn{4}{|l|}{ Student Programs } \\
\hline 15. Earmarking funds for students to study or work abroad & 3.58 & 1.07 & High \\
\hline 16. Conducting a meeting place for students to discuss international issues & 3.68 & .98 & High \\
\hline Category mean & 3.63 & .99 & High \\
\hline Overall Mean & 3.72 & .78 & High \\
\hline
\end{tabular}

The predictors of institutional internationalization efforts are presented in Table 4. Specifically, it displays the value of the beta coefficients, the R squared, $t \& F$ value, the probability value, and the remarks whether the influence of the independent variables is significant or not. It can be seen also in the table the single and combined influence of top management leadership skills and faculty research capability to institutional internationalization efforts. 
TABLE 4. Predictors of institutional internationalization efforts

\begin{tabular}{lllll}
\hline \hline Predictors & Beta Coefficients $/ R^{2}$ & $\boldsymbol{t} / \boldsymbol{F}$ & $\boldsymbol{p}$-value & Remarks \\
\hline Top Mgt. Leadership Skills & 0.45 & 8.78 & 0.00 & $\mathrm{~S}$ \\
Faculty Research Cap. & 0.11 & 2.20 & 0.03 & $\mathrm{~S}$ \\
Combined & 0.28 & 75.34 & 0.00 & $\mathrm{~S}$ \\
\hline \hline
\end{tabular}

TABLE 5. Lived experiences of participants pertaining to institutional internationalization efforts

\begin{tabular}{|c|c|c|c|c|}
\hline Issues Probed & Core Ideas & Codes/Categories & Essential Themes & $\begin{array}{l}\text { Supporting Theoretical } \\
\text { Perspective }\end{array}$ \\
\hline \multirow[t]{2}{*}{$\begin{array}{l}\text { Experiences of faculty on } \\
\text { their top management in } \\
\text { dealing with institutional } \\
\text { internationalization ef- } \\
\text { forts }\end{array}$} & $\begin{array}{l}\text { - Sending faculty to } \\
\text { trainings and workshops } \\
\text { - providing reimburse- } \\
\text { ment on incurred ex- } \\
\text { penses when necessary } \\
\text { during research activity } \\
\text { - providing fund source } \\
\text { to engage faculty in the } \\
\text { research projects - pro- } \\
\text { viding financial support } \\
\text { on faculty attendance } \\
\text { to national and interna- } \\
\text { tional conferences on } \\
\text { research - inviting expert } \\
\text { resource speaker to train } \\
\text { faculty how to develop } \\
\text { appropriate research } \\
\text { skills }\end{array}$ & $\begin{array}{l}\text { Having full support from } \\
\text { the top management }\end{array}$ & $\begin{array}{l}\text { Financial and moral sup- } \\
\text { port from the top man- } \\
\text { agement }\end{array}$ & $\begin{array}{ll}\text { Contingency } & \text { Approach } \\
\text { Theory } & \end{array}$ \\
\hline & $\begin{array}{l}\text { - granting request to } \\
\text { travel for presentation } \\
\text { - considering subject } \\
\text { deloading - informing } \\
\text { well the faculty on the } \\
\text { research projects }\end{array}$ & $\begin{array}{l}\text { Feeling important in the } \\
\text { organization }\end{array}$ & & \\
\hline \multirow[t]{2}{*}{$\begin{array}{l}\text { Experiences of Faculty in } \\
\text { Research engagement to- } \\
\text { wards institutional inter- } \\
\text { nationalization efforts }\end{array}$} & $\begin{array}{l}\text { - involving the Top } \\
\text { Management in Research } \\
\text { Activity - providing funds } \\
\text { for research publication } \\
\text { - sourcing out Funds } \\
\text { from other agencies - } \\
\text { supported by immedi- } \\
\text { ate supervisor when } \\
\text { engaged in research } \\
\text { endeavor }\end{array}$ & $\begin{array}{l}\text { Experiencing support } \\
\text { from the top manage- } \\
\text { ment }\end{array}$ & $\begin{array}{l}\text { Time management, disci- } \\
\text { pline and support from } \\
\text { the administration }\end{array}$ & $\begin{array}{l}\text { Hierarchy of Need The- } \\
\text { ory }\end{array}$ \\
\hline & $\begin{array}{l}\text { - Managing time in do- } \\
\text { ing/engaging in research } \\
\text { - Learning in publish- } \\
\text { ing research articles - } \\
\text { Beating deadlines for } \\
\text { submission of other } \\
\text { requirements - Man- } \\
\text { aging hectic schedule } \\
\text { for classes - Improving } \\
\text { research paper needs } \\
\text { patience }\end{array}$ & $\begin{array}{l}\text { Managing time and keep- } \\
\text { ing self-discipline }\end{array}$ & & \\
\hline
\end{tabular}


TABLE 5. Continue...

\begin{tabular}{|c|c|c|c|c|}
\hline Issues Probed & Core Ideas & Codes/Categories & Essential Themes & $\begin{array}{l}\text { Supporting Theoretical } \\
\text { Perspective }\end{array}$ \\
\hline $\begin{array}{l}\text { Effects of their ex- } \\
\text { periences as faculty } \\
\text { researcher with the top } \\
\text { management support } \\
\text { towards institutional } \\
\text { internationalization } \\
\text { efforts }\end{array}$ & $\begin{array}{l}\text { - Learning more to be- } \\
\text { come a good researcher } \\
\text { - Working hard to im- } \\
\text { prove skills in research } \\
\text { - Managing time to ac- } \\
\text { commodate all activities } \\
\text { - Striving harder to } \\
\text { develop self-esteem as } \\
\text { a researcher - Work- } \\
\text { ing harder to become } \\
\text { an expert researcher } \\
\text { - Working harder to } \\
\text { publish more research } \\
\text { articles } \\
\text { - Developing self-trust } \\
\text { and faith in the team - } \\
\text { Securing place as part of } \\
\text { the academic community } \\
\text { - Improving trust to } \\
\text { the management team } \\
\text { - Attending to trainings } \\
\text { and write shops - Attend- } \\
\text { ing to conferences and } \\
\text { for a Developing self- } \\
\text { confidence and sense } \\
\text { of purpose - Preparing } \\
\text { to be a respectable and } \\
\text { discipline researcher } \\
\text { - Becoming more re- } \\
\text { sponsible researcher - } \\
\text { motivating others to join } \\
\text { and research work }\end{array}$ & $\begin{array}{l}\text { Achieving fulfillment and } \\
\text { source of influence to } \\
\text { others }\end{array}$ & $\begin{array}{l}\text { Developing profession- } \\
\text { alism and personal } \\
\text { improvement }\end{array}$ & $\begin{array}{l}\text { Hierarchy of Need The- } \\
\text { ory }\end{array}$ \\
\hline
\end{tabular}

Table 6 shows the core ideas or concepts and the emerging themes, which are characterized by the experiences of the informants pertaining to the role of participants' experiences in the shaping of their attitude and commitment in working towards institutional internationalization efforts.
Three essential themes have emerged from the interviews and focus group discussions with the participants, namely sense of purpose and responsiveness to one's duties and responsibilities, motivation ignites everyone in action, and appropriate research skills produce quality output.

TABLE 6. Role of participants' experiences on top management leadership skills and faculty research capability in shaping their beliefs, attitudes and commitments

\begin{tabular}{|c|c|c|c|c|}
\hline Issues Probed & Core Ideas & Codes/Categories & Essential Themes & $\begin{array}{l}\text { Supporting Theoretical } \\
\text { Perspective }\end{array}$ \\
\hline Belief & $\begin{array}{l}\text { - Due to the mandates } \\
\text { in the } 4 \text {-fold function of } \\
\text { faculty in SUC - Because } \\
\text { of CHED mandates - } \\
\text { Professional growth } \\
\text { - Earning points for } \\
\text { promotion - Commen- } \\
\text { surate rank and salary } \\
\text { - Producing knowledge } \\
\text { discovery - Innovating } \\
\text { new technology }\end{array}$ & $\begin{array}{l}\text { Self-gratification and } \\
\text { sense of purpose as } \\
\text { faculty }\end{array}$ & $\begin{array}{l}\text { Being purposeful and re- } \\
\text { sponsive to one's duties } \\
\text { and responsibilities }\end{array}$ & $\begin{array}{l}\text { Hierarchy of Needs The- } \\
\text { ory }\end{array}$ \\
\hline
\end{tabular}


TABLE 6. Continue...

\begin{tabular}{|c|c|c|c|c|}
\hline Issues Probed & Core Ideas & Codes/Categories & Essential Themes & $\begin{array}{l}\text { Supporting Theoretical } \\
\text { Perspective }\end{array}$ \\
\hline Attitudes & $\begin{array}{l}\text { - Desire for knowledge } \\
\text { and skills in research } \\
\text { Motivated by knowledge } \\
\text { produced after engaging } \\
\text { in research } ~-~ A w a r e n e s s \\
\text { to points earned for pro- } \\
\text { motion - Awareness of } \\
\text { rewards and incentives } \\
\text { given by school } \bullet \text { Had the } \\
\text { chance to travel abroad } \\
\text { - Awareness of financial } \\
\text { support given by the ad- } \\
\text { ministration }\end{array}$ & $\begin{array}{l}\text { Intrinsically and Extrin- } \\
\text { sically motivated }\end{array}$ & $\begin{array}{l}\text { Becoming motivated to } \\
\text { ignite everyone to do re- } \\
\text { search }\end{array}$ & Motivation Theory \\
\hline Commitment & $\begin{array}{l}\text { To develop technical } \\
\text { skills needed in doing } \\
\text { research - To increase } \\
\text { skills in conceptualizing } \\
\text { research topic • To im- } \\
\text { prove interpersonal rela- } \\
\text { tionship among the fac- } \\
\text { ulty } \bullet \text { To encourage oth- } \\
\text { ers to do research } \bullet \text { To } \\
\text { have exposure to the new } \\
\text { trends in research } \bullet \text { Pub- } \\
\text { lish research }\end{array}$ & $\begin{array}{l}\text { Enhancing } \\
\text { skills }\end{array}$ & $\begin{array}{l}\text { Becoming more research } \\
\text { engaged }\end{array}$ & Contingency Theory \\
\hline
\end{tabular}

TABLE 7. Joint display of salient qualitative and quantitative findings

\begin{tabular}{|c|c|c|c|c|}
\hline $\begin{array}{l}\text { Aspects or Fo- } \\
\text { cal Points }\end{array}$ & Quantitative Findings & Qualitative Findings & $\begin{array}{l}\text { Nature of Data Integra- } \\
\text { tion }\end{array}$ & $\begin{array}{l}\text { Axiological Implica- } \\
\text { tions }\end{array}$ \\
\hline $\begin{array}{l}\text { Top Manage- } \\
\text { ment Leader- } \\
\text { ship Skills }\end{array}$ & $\begin{array}{l}\text { Table } 1 \text { in Top Man- } \\
\text { agement Leadership } \\
\text { Skills under indicator } 1 \\
\text { - Administrative Skills } \\
\text { on item about being ef- } \\
\text { fective with the detailed } \\
\text { aspects of their work } \\
\text { (item 1) and under indi- } \\
\text { cator 3- Conceptual Skills } \\
\text { about making strategic } \\
\text { plans for the company } \\
\text { (item } 12 \text { ) are both rated } \\
\text { High at } M=4.14 \text {, and } M \\
=4.08 \text {, respectively }\end{array}$ & $\begin{array}{l}\text { On Table 4, the following } \\
\text { data express parallelism } \\
\text { in terms of findings with } \\
\text { the identified quantita- } \\
\text { tive data: A category of } \\
\text { core ideas named Having } \\
\text { full support from top } \\
\text { management emerged } \\
\text { from thematic analysis. } \\
\text { It talks about providing } \\
\text { fund source to engage } \\
\text { faculty in the research } \\
\text { project, and providing } \\
\text { financial support on } \\
\text { faculty attendance to na- } \\
\text { tional and international } \\
\text { conferences on research }\end{array}$ & Merging-converging & $\begin{array}{l}\text { Top management leader- } \\
\text { ship is the ability and } \\
\text { willingness to take own- } \\
\text { ership of the organiza- } \\
\text { tion, combined with an } \\
\text { intrinsic drive to do what } \\
\text { is best for the organiza- } \\
\text { tion }\end{array}$ \\
\hline
\end{tabular}


TABLE 7. Continue....

\begin{tabular}{|c|c|c|c|c|}
\hline $\begin{array}{l}\text { Aspects or Fo- } \\
\text { cal Points }\end{array}$ & Quantitative Findings & Qualitative Findings & $\begin{array}{l}\text { Nature of Data Integra- } \\
\text { tion }\end{array}$ & $\begin{array}{l}\text { Axiological Implica- } \\
\text { tions }\end{array}$ \\
\hline \multirow{3}{*}{$\begin{array}{l}\text { Faculty Re- } \\
\text { search Capabil- } \\
\text { ity }\end{array}$} & $\begin{array}{l}\text { Table } 1 \text { in Top Man- } \\
\text { agement Leadership } \\
\text { Skills under indicator } \\
2 \text { - Interpersonal Skills } \\
\text { on item about using } \\
\text { emotional energy to } \\
\text { motivate others (item } \\
\text { 11) and sensing the } \\
\text { emotional undercurrent } \\
\text { in my group (item 8) } \\
\text { are both rated High at } \\
M=3.92 \text {, and } M=3.86 \text {, } \\
\text { respectively }\end{array}$ & $\begin{array}{l}\text { On Table 4, the following } \\
\text { data express parallelism } \\
\text { in terms of findings with } \\
\text { the identified quantita- } \\
\text { tive data: A category of } \\
\text { core ideas named Feeling } \\
\text { important in the organi- } \\
\text { zation emerged from the- } \\
\text { matic analysis. It talks } \\
\text { about informing well the } \\
\text { faculty on the research } \\
\text { projects, and considering } \\
\text { subject deloading }\end{array}$ & Merging - converging & $\begin{array}{l}\text { Having a high degree of } \\
\text { emotional intelligence } \\
\text { will enable the leader to } \\
\text { deal with such situations } \\
\text { effectively and objec- } \\
\text { tively while not avoiding } \\
\text { the underlying issues }\end{array}$ \\
\hline & $\begin{array}{l}\text { Table } 2 \text { in Faculty Re- } \\
\text { search Capability under } \\
\text { indicator C -Research } \\
\text { Capability along Tech- } \\
\text { nical Skills on items } \\
\text { about handling data } \\
\text { correctly (item 1) and } \\
\text { encoding the study using } \\
\text { computer (item 2) are } \\
\text { both rated very high at } \\
M=4.43 \text {, and } M=4.39 \text {, } \\
\text { respectively }\end{array}$ & $\begin{array}{l}\text { On Table 4, the following } \\
\text { data express parallelism } \\
\text { in terms of findings with } \\
\text { the identified quanti- } \\
\text { tative data: A category } \\
\text { of core ideas named } \\
\text { Developing patience and } \\
\text { determination emerged } \\
\text { from thematic analysis. } \\
\text { It talks about working } \\
\text { harder to become an } \\
\text { expert researcher, and } \\
\text { working hard to improve } \\
\text { skills in research }\end{array}$ & Merging-converging & $\begin{array}{l}\text { The research capability } \\
\text { is a logically distinct } \\
\text { grouping of the entire } \\
\text { research process, includ- } \\
\text { ing the resources and } \\
\text { technologies, to produce } \\
\text { discrete output. }\end{array}$ \\
\hline & $\begin{array}{l}\text { Table } 2 \text { in Faculty Re- } \\
\text { search Capability under } \\
\text { indicator A -Research } \\
\text { Capability along Compu- } \\
\text { tational Skills on items } \\
\text { about are determining } \\
\text { appropriate statistical } \\
\text { tool (item 4) and using } \\
\text { the computer (SPSS) or } \\
\text { other statistical software } \\
\text { to analyze data (item 2) } \\
\text { are both rated high at } \\
M=4.16 \text {, and } M=4.07, \\
\text { respectively }\end{array}$ & $\begin{array}{l}\text { On Table 4, the follow- } \\
\text { ing data express paral- } \\
\text { lelism in terms of find- } \\
\text { ings with the identified } \\
\text { quantitative data: } \\
\text { A category of core ideas } \\
\text { named Developing } \\
\text { patience and determi- } \\
\text { nation emerged from } \\
\text { thematic analysis. It } \\
\text { talks about working } \\
\text { harder to become an } \\
\text { expert researcher, and } \\
\text { working hard to improve } \\
\text { skills in research }\end{array}$ & Merging-converging & $\begin{array}{l}\text { Research capability is the } \\
\text { facility or potential of in- } \\
\text { dividuals, organizations, } \\
\text { and systems to under- } \\
\text { take and disseminate ef- } \\
\text { fectively and efficiently } \\
\text { high-quality research. }\end{array}$ \\
\hline $\begin{array}{l}\text { Institutional } \\
\text { International- } \\
\text { ization Efforts }\end{array}$ & $\begin{array}{l}\text { Table } 2 \text { in Institutional } \\
\text { Internationalization } \\
\text { Efforts under indicator } \\
\text { D - External Funding } \\
\text { on items about receiv- } \\
\text { ing funding from other } \\
\text { government agencies } \\
\text { (item 11) and Indicator } \\
\text { A - Articulated Commit- } \\
\text { ment about conducting } \\
\text { formal assessment of } \\
\text { internationalization in } \\
\text { the last three years (item } \\
\text { 1) are both rated High at } \\
M=3.90 \text {, and } M=3.82, \\
\text { respectively }\end{array}$ & $\begin{array}{l}\text { On Table 4, the following } \\
\text { data express parallelism } \\
\text { in terms of findings with } \\
\text { the identified quantita- } \\
\text { tive data: A category of } \\
\text { core ideas named Expe- } \\
\text { riencing support from } \\
\text { the top management } \\
\text { emerged from thematic } \\
\text { analysis. It talks about } \\
\text { sourcing out funds from } \\
\text { other agencies, and pro- } \\
\text { viding financial support } \\
\text { on faculty attendance } \\
\text { to national and interna- } \\
\text { tional conferences on } \\
\text { research }\end{array}$ & Merging-converging & $\begin{array}{l}\text { Articulated commitment } \\
\text { is the extent to which } \\
\text { an institution has writ- } \\
\text { ten statements or estab- } \\
\text { lished policies support- } \\
\text { ing internationalization }\end{array}$ \\
\hline
\end{tabular}


TABLE 7. Continue....

\begin{tabular}{|c|c|c|c|c|}
\hline $\begin{array}{l}\text { Aspects or Fo- } \\
\text { cal Points }\end{array}$ & Quantitative Findings & Qualitative Findings & $\begin{array}{l}\text { Nature of Data Integra- } \\
\text { tion }\end{array}$ & $\begin{array}{l}\text { Axiological Implica- } \\
\text { tions }\end{array}$ \\
\hline & $\begin{array}{l}\text { Table } 2 \text { in Institutional } \\
\text { Internationalization } \\
\text { Efforts under indicator } \\
\text { B - Academic Offerings } \\
\text { on items about admin- } \\
\text { istering international } \\
\text { field study for credit } \\
\text { (item 5) and Indicator } \\
F \text { - Student Programs } \\
\text { about earmarking funds } \\
\text { for students to study or } \\
\text { work abroad (item } 1 \text { ed } \\
\text { High at } M=3.62 \text {, and } M \\
=3.58 \text {, respectively }\end{array}$ & $\begin{array}{l}\text { On Table 4, the following } \\
\text { data express parallelism } \\
\text { in terms of findings with } \\
\text { the identified quantita- } \\
\text { tive data: A category of } \\
\text { core ideas named Expe- } \\
\text { riencing support from } \\
\text { the top management } \\
\text { emerged from thematic } \\
\text { analysis. It talks about } \\
\text { sourcing out funds from } \\
\text { other agencies, and pro- } \\
\text { viding financial support } \\
\text { on faculty attendance } \\
\text { to national and interna- } \\
\text { tional conferences on } \\
\text { research }\end{array}$ & Merging-converging & $\begin{array}{l}\text { An institution's empha- } \\
\text { sis on internationaliza- } \\
\text { tion was measured not } \\
\text { only in its foreign lan- } \\
\text { guage offerings, but also } \\
\text { in its general education } \\
\text { requirements }\end{array}$ \\
\hline $\begin{array}{l}\text { Significance } \\
\text { of the Influ- } \\
\text { ence of Faculty } \\
\text { Research Ca- } \\
\text { pability to } \\
\text { Institutional } \\
\text { International- } \\
\text { ization Efforts }\end{array}$ & $\begin{array}{l}\text { Table } 3 \text { in Predictors } \\
\text { of Institutional Inter- } \\
\text { nationalization Efforts } \\
\text { under variable } 1 \text { - Faculty } \\
\text { Research Capability is } \\
\text { significant with } p \text {-value } \\
0.029(p<.05) \text { and stan- } \\
\text { dardized beta value of } \\
0.113\end{array}$ & $\begin{array}{l}\text { On Table 4, the following } \\
\text { data express parallelism } \\
\text { in terms of findings with } \\
\text { the identified quantita- } \\
\text { tive data: A category of } \\
\text { core ideas named Having } \\
\text { support from the top } \\
\text { management emerged } \\
\text { from thematic analysis. } \\
\text { It talks about inviting } \\
\text { expert resource speaker } \\
\text { to train faculty how to } \\
\text { develop appropriate } \\
\text { research skills, and send- } \\
\text { ing faculty to trainings } \\
\text { and workshops }\end{array}$ & Merging-converging & $\begin{array}{l}\text { Faculty involvement is } \\
\text { key to internationaliza- } \\
\text { tion. Faculty have the } \\
\text { most direct contact with } \\
\text { students and create the } \\
\text { curriculum. }\end{array}$ \\
\hline $\begin{array}{l}\text { Significance of } \\
\text { the Influence } \\
\text { of Top Manage- } \\
\text { ment Leader- } \\
\text { ship Skills to } \\
\text { Institutional } \\
\text { International- } \\
\text { ization Efforts }\end{array}$ & $\begin{array}{l}\text { Table } 4 \text { in Predictors } \\
\text { of Institutional Inter- } \\
\text { nationalization Efforts } \\
\text { under variable } 2-\text { Top } \\
\text { Management Leadership } \\
\text { Skills is significant with } \\
\text { p-value } 0.000 \quad(p<.05) \\
\text { and standardized beta } \\
\text { value of } 0.453\end{array}$ & $\begin{array}{l}\text { On Table 4, the following } \\
\text { data express parallelism } \\
\text { in terms of findings with } \\
\text { the identified quantita- } \\
\text { tive data: A category of } \\
\text { core ideas named Expe- } \\
\text { riencing support from } \\
\text { the top management } \\
\text { emerged from thematic } \\
\text { analysis. It talks about } \\
\text { providing funds for } \\
\text { research publications, } \\
\text { involving the top man- } \\
\text { agement in research } \\
\text { activity, and sourcing } \\
\text { out funds from other } \\
\text { agencies }\end{array}$ & Merging-converging & $\begin{array}{l}\text { Leadership represents } \\
\text { the effort that institu- } \\
\text { tions put forth to seek } \\
\text { external funds specif- } \\
\text { ically earmarked for } \\
\text { international education } \\
\text { programs and activities } \\
\text { and the extent to which } \\
\text { they received funding } \\
\text { dedicated to advancing } \\
\text { internationalization. }\end{array}$ \\
\hline
\end{tabular}

\section{DISCUSSION}

This chapter presents a discussion of the results and implications of the findings of the study. The first section is discussion of quantitative and qualitative findings. On the other hand, the second part is the discussion of salient fea- tures of quantitative and qualitative results Status of Participant's Assessment on Top Management Leadership Skills and Faculty Research Capability The level of Top Management Leadership Skills as assessed by the participants was described as high. This means that Top Management Lead- 
ership Skills is oftentimes observed among the State Universities and Colleges in Region XI. This further denotes that the top management of SUCs in Region XI had effective leadership skills. The results conform to the previous research of Fiedler (1967) which revealed that leadership is the key to progress and survival of any organization. Likewise, the results acknowledged the study of Sinkovics, Penz, and Ghauri (2008) which stated that leadership represents a range of behavior such that he will do planning, structuring of tasks, controlling and his relationship with staff in the organization.

However, the faculty research capability among the SUCs was rated very high. This means that the faculty research capability is always observed among SUCs in Region XI. In established research institutions, expansion of research is often attempted by adding faculty members to existing units and providing mentoring and infrastructure to maximize individual success. This means further that Motivation System Theory (MST), as a lens, to help us better understand faculty's engagement in research and teaching.

\section{Extent of Institutional Internationalization Efforts of the SUCs as assessed by the faculty}

The findings reveal a high level of institutional internationalization efforts. This means that institutional internationalization efforts are oftentimes observed among the SUCs in the Region XI. Likewise, the research conducted in Southern Philippines on readiness for internationalization of higher education system shows that HEIs are ready in terms of mission, goal, and plan. In the area of foundation as reflected in their strategic plans and goals, their internationalization policies of the institutions, are articulated as part of their basic policies which have concreteness (Dimasindel \& Salam, 2018). Hence, institutional response to globalization's challenges and opportunities also include the formation of organizational structures that oversee internationalization concerns. Faculty must be involved in the international activities performing new roles with job description and responsibility sharing description base on the competencies provided. Thus, HEIs must be ready in terms of structure and staff. Significance of the Influence of the Leadership Skills and Faculty Research Capability on the Institutional Internationalization Efforts of the SUCs.

The results of multiple regression analysis reveal that both top management leadership skills and faculty research capability significantly influence Institutional Internationalization Efforts. In particular, securing administrative commitment to post-award staff support, hiring research active faculty with reduced teaching loads, and modifying tenure and promotion criteria to reward research productivity are the solutions done for research development.

Likewise, building research capacity in an emerging research institution also requires assessment of research management practices and identification of transitional practices to promote the evolving research agenda (Huenneke et al., 2017). Furthermore, institutional response to globalization's challenges and opportunities also include the formation of organizational structures that oversee internationalization concerns. Faculty must be involved in the international activities performing new roles with job description and responsibility sharing description base on the competencies provided. Thus, HEIs must be ready in terms of structure and staff.

Lived Experiences of the Participants as they Engaged in Research for Institutional Internationalization Efforts.

One of the essential themes that emerged from the interviews with the participants is personal and professional growth. This was supported by three categories such as developing patience and determination, developing confidence and sense of purpose and achieving fulfillment and source of influence to others. This result is supported by Huenneke et al. (2017), for developing research culture, several strategies are aimed on improving base on standard model: cluster hiring, revision of institutional policies and infrastructure, and systematic prioritization of research for administrator and for individual faculty members.

Thus, securing administrative commitment to post-award staff support, hiring research active faculty with reduced teaching loads, and modifying tenure and promotion criteria to reward research productivity are the solutions done for research development.

Likewise, building research capacity in an emerging research institution also requires assessment of research management practices and identification of transitional practices to promote the evolving research agenda (Huenneke et al., 2017).

Lived Experiences of Teachers on the Leadership Skills of Their Heads Among the Factors that Contributed to Institutional Internationalization Efforts.

The generated essential theme based on the teachers' experiences on the leadership of their heads among the factors that contributed for institutional internationalization efforts is financial and moral support from the top management. This was further supported by two emerging categories such as having support from the top management, and feeling important in the organization. Moreover, said result was elucidated based on the findings that one of the perennial problems in terms of internationalization 
is the lack of financial support or budget. According to Dimasindel and Salam (2018) on their research for readiness of HEIs in Southern Philippines in terms of internationalization of higher education system in the Philippines is that allotment for the program were not being prioritized by the HEIs. It further implies that the budget meetings and financial targets are also not done frequently. This perhaps is due to their insufficient allotment for the projects, time for budgeting meetings, and financial targets. Thus, providing an idea that the budget for internationalization is not entirely secured that might affect the readiness of HEIs. Henceforth, the HEIs must be committed in embracing the challenges of the internationalization of educational system in the Philippines, and must respond on the rapidly changing globalized world that the CHED described to be an era of "global competitiveness".

Role of Experiences in Shaping Belief, Attitude and Commitment with Respect to institutional internationalization efforts The first theme that emerged from the interviews with the participants is sense of awareness and responsiveness to one's duties and responsibilities. This theme highlighted important indicator which is self-gratification and sense of purpose as faculty. This supports the study of the Center for Creative Leadership highlighted four (4) core leadership skills for every career and they are as follows: self awareness, communication, influence, and learning agility. Self - awareness means understanding one's strengths and weaknesses. Another skill which is vital for successful leaders is "communicating information and ideas." Good and open communication is essential to the success of any organization. Communication should be active, personal, and ongoing. It is necessary for leaders to keep in mind that miscommunication is never the mistake of the recipient alone. Lots of talking does not necessarily mean lots of communicating. Real communication means that there is common understanding as a result (Fiedler, 1967).

The second theme is that motivation plays a significant role to propel everyone in action. This forms scopes like intrinsically and extrinsically motivated. This is considered as a positive change in the participants as described by Baker and Fine (2014) that when "leaders and followers make each other advance to a higher level of morality and motivation." Moreover, Abraham Maslow's Hierarchy of Need Theory stated that humans have five sets of need that are arranged in hierarchy. He contends that people start by trying to satisfy their most basic or compelling needs and progress toward the most fulfilling. These are the psychological needs, the safety needs, the relationship needs, the esteem needs, and the self-actualization needs. In this the- ory, it appears that the further up the scale an individual move, the more the reward or motivators move from the external environment to an internal need. It also becomes more difficult to influence motivation, since material rewards become less relevant and internal rewards become more difficult to identify and address. In order to enhance organizational performance, it is important that the organization recognize the individual need and provide opportunities for satisfaction.

Lastly, the third theme emphasized on strengthening research capability among faculty researcher. This possesses the category of enhancing research skills. This is also another manifestation of positive change on participants' behavior. It can be noted that in established research institutions, expansion of research is often attempted by adding faculty members to existing units and providing mentoring and infrastructure to maximize individual success. The University of Arizona Cancer Center (UACC) was successful in this kind of universal approach, however, the experiences in the Northern Arizona University (NAU) is quite not positive when they hire individual talented researches for many years which ended up in leaving the university for failing to achieved hope for productivity.

\section{Data Integration on the Salient Quantitative and Quali- tative Findings}

The fifth research question of this study involves the corroboration of both quantitative and qualitative findings. This section presents the implications of each important point. Top Management Leadership Skills. The corroborated findings denote that top management leadership has the ability and willingness to take ownership of the organization, combined with an intrinsic drive to do what is best for the organization (The Importance of Leadership to Organizational Success) and having a high degree of emotional intelligence will enable the leader to deal with such situations effectively and objectively while not avoiding the underlying issues (Empathy and emotional intelligence). These findings conform to the study conducted by Weathersby (1999) that leadership is focused on creating a common vision and motivating people to contribute meaningfully to the attainment of the vision and encouraging them to align their self-interest with that of the organization; it is persuading and not commanding. Leadership is a process that encompasses the behavior of the leader, the behavior of the followers, and the environment of the situation.

Faculty Research Capability. The integration of findings imply that the research capability is a logically distinct grouping of the entire research process, including the resources 
and technologies, to produce discrete output; and more so, research capability is the facility or potential of individuals, organizations, and systems to undertake and disseminate effectively and efficiently high-quality research. (The Research Capability of Ilocos Sur Polytechnic State College: A Basis for A Capability Enhancement Program by de la Cruz). These findings are similar to the study conducted by Bosch and Taylor (2011), which revealed that early phrases are marked by "hand holding" management, institutional emphasis on teaching, a faculty mindset that research is intimidating, and centralized research mission with deans' focus on teaching output and research activity rather than research quality and outcomes. Transition through a "broadening" phase to the "honing" phase is marked by increased emphasis on research relative to teaching, decentralization of the research mission into college and department priorities, increase collaborations, and a growing focus on recruitment of high-quality researchers and post graduate students.

Institutional Internationalization Efforts. The verified quantitative and qualitative findings pointed out that articulated commitment is the extent to which an institution has written statements or established policies supporting internationalization and an institution's emphasis on internationalization was measured not only in its foreign language offerings, but also in its general education requirements (Measuring Internationalization at Research Universities by: Madeleine F. Green). These findings it indicates the importance of operations which highlights appropriate organizational structures, systems for coordination, communication and cooperation, adequate financial support and resource allocation systems (Knight, 2008). Hence, Internationalization of HEIs becomes a subject of interest by several academic institutions as policymakers and institutional administrators are now paying attention to this phenomenon because economic performance is affected by the growing cross-border flows of knowledge, knowledge-workers, and students (Organisation for Eco- nomic Co-operation and Development, 2008; Pama, 2015).

\section{CONCLUSION AND RECOMMENDATIONS}

This chapter presents the conclusions drawn from the findings and the recommendations made regarding the study.

\section{Conclusion}

1. The status of faculty research capability in the five State Universities and Colleges in Region XI was rated very high, which implies that faculty research capability was oftentimes evident in the SUCs in Region XI.

2. The extent of the institutional internationalization efforts of the SUCs as assessed by the faculty in the SUCs in Region $\mathrm{XI}$ obtained an overall mean value with a descriptive equivalent level of high which means that institutional internationalization efforts were oftentimes observed.

3. The top management leadership skills and faculty research capability had both significantly influenced institutional internationalization efforts in the SUCs in Region XI. This means that top management leadership skills influence more the institutional internationalization efforts.

4. With regard to data integration of the salient findings, both quantitative and qualitative findings manifested parallel results. Likewise, these corroborated findings mean that the quantitative and qualitative findings merged and converged with each other.

\section{Recommendations}

Based on the findings of the study, the following recommendations are proposed:

1. The top management among the SUCs in the region XI is supportive to the internationalization efforts, it is suggested that the SUCs in region XI shall innovate more schemes that will attract more faculty to engage not just in local but in regional, national and international researches.

2. Future studies may venture on the influence of emerging variables from qualitative findings. This includes variables like innovative leadership and creative services.

\section{REFERENCES}

Almonte-Acosta, S. A. (2007). Developing research culture in philippine higher education institutions: Perspectives of university faculty rose marie salazar-clemeñ (Unpublished doctoral dissertation). College of Education De La Salle University Manila, Manila,Philippines.

Altbach, P. G., \& Knight, J. (2007). The internationalization of higher education: Motivations and realities. Journal of Studies in International Education, 11(3-4), 290-305. doi:https://doi.org/10.1177/1028315307303542

Baker, A. J., \& Fine, P. R. (2014). Surviving parental alienation: A journey of hope and healing. London, UK: Rowman \& Littlefield Lantham.

Bordean, O.-N., \& Borza, A. (2013). Internationalization of higher education institutions: The case of Romania. ProcediaSocial and Behavioral Sciences, 92, 98-103. doi:https://doi.org/10.1016/j.sbspro.2013.08.643 
Bosch, A., \& Taylor, J. (2011). A proposed framework of institutional research development phases. Journal of Higher Education Policy and Management, 33(5), 443-457. doi:https://doi.org/10.1080/1360080X.2011.585742

Brix, S., Svavarsson, J., \& Leese, F. (n.d.). A multi-gene analysis reveals multiple highly divergent lineages of the isopod chelator insignis (Hansen, 1916) south of Iceland. Retrieved from https://bit.1y/2LQ1rm6

Christensen, C. M., \& Eyring, H. J. (2011). The innovative university: Changing the DNA of higher education from the inside out. New York, NY: John Wiley \& Sons.

Commission on Higer Education. (2016). Pathway to equity, relevance and advancement in research, innovation and extension in Philippine higher education. Retrieved from https://bit.1y/39AdwnI

Commission on Higher Education. (2012). Policy-Standard to Enhance Quality Assurance (QA) in Philippine higher education through an outcome -based and typology-based QA. Retrieved from https://bit.1y/3bIhr4D

Creswell, J. W., \& Poth, C. N. (2016). Qualitative inquiry and research design: Choosing among five approaches. New York, NY: Sage Publications.

Dimasindel, M. R., \& Salam, N. D. (2018). Readiness of higher education in Southern Philippines: Internationalization of higher education system in the Philippines. In 3rd International Conference on Education, Sports, Arts and Management Engineering, California, CA.

Durie, A., \& Beshir, E. (2016). Leadership effectiveness in higher education institutions: The IPA approach. Arabian Journal Business Management Review, 6(243), 1-4. doi:https://doi.org/10.4172/2223-5833.1000243

Fiedler, F. E. (1967). A theory of leadership effectiveness. New York, NY: McGraw-Hill.

Godreau, I. P. (2015). Scripts of blackness: Race, cultural nationalism, and US colonialism in Puerto Rico. Lllinois, IL: University of Illinois Press.

Huenneke, L. F., Stearns, D. M., Martinez, J. D., \& Laurila, K. (2017). Key strategies for building research capacity of university faculty members. Innovative Higher Education, 42(5-6), 421-435. doi:https://doi.org/10.1007/s10755-017-9394-y

Japan International Cooperation Agency. (2015). Higher education sector in the Philippines. Retrieved from https:// bit.ly/3qpiDOB

Jonathan, L. (2016). The research capability of ilocos sur polytechnic state college: A basis for a capability enhancement program. International Journal of Management and Social Sciences Research, 5(7), 41-44.

Katz, R. L. (2009). Skills of an effective administrator. Boston, MA: Harvard Business Review Press.

Knight, J. (2008). Higher education in turmoil: The changing world of internationalization. Saane, Switzerland: Brill Sense.

Kolodziejczak, M., Szarska, J., \& Edelmuller, A. (2019). Continuous improvement in education: Adaptation of kaizen philosophy on the example of the student project AGH leanline. International Journal of Business and Economic Affairs, 4(4), 149-162. doi:https://doi.org/10.24088/ijbea-2019-44001

Mughal, M. S., Ross, A. D., \& Fearon, D. J. (2017). Development needs of middle managers in higher education institutions: A case study of a post 1992 New University in UK. International Journal of Business and Administrative Studies, 3(6), 239-259. doi:https://doi.org/10.20469/ijbas.3.10005-6

Nordin, N. (2012). The influence of leadership behavior and organizational commitment on organizational readiness for change in a higher learning institution. Asia Pacific Education Review, 13(2), 239-249. doi:https://doi.org/10.1007/ s12564-011-9200-y

Organisation for Economic Co-operation and Development. (2008). Tertiary education for the knowledge society. Retrieved from https://bit.1y/3soCcYV

Ozyurek, . U. Y., H. (2016). Flexible budgeting under time-driven activity based cost as a tool in management accounting: Application in educational institution. Journal of Administrative and Business Studies, 2(2), 64-70. doi:https://doi.org/ $10.20474 /$ jabs-2.2.2

Pama, R. (2015). The role of education in the pursuit of globalization and internationalization. In Seminar on Leveling Up to ASEAN 2015 Building Linkages and Securing Grants, London, UK.

Rosenthal, S. B. (1987). The pragmatic a priori: Lewis and dewey. The Southern Journal of Philosophy, 25(1), 109-121.

Sanyal, B. C., \& Varghese, N. (2006). Research capacity of the higher education sector in developing countries. In UNESCO Forum on Higher Education, Research and Knowledge, Paris, France.

Sathye, M. (2004). Leadership in higher education: A qualitative study. Retrieved from https://bit. 1y/2LJwH6p 
Selingo, J. J. (2013). College (un) bound: The future of higher education and what it means for students. California, CA: Houghton Mifflin Harcourt.

Shenton, A. K. (2004). Strategies for ensuring trustworthiness in qualitative research projects. Education for Information, 22(2), 63-75. doi:https://doi.org/10.3233/EFI-2004-22201

Sinkovics, R. R., Penz, E., \& Ghauri, P. N. (2008). Enhancing the trustworthiness of qualitative research in international business. Management International Review, 48(6), 689-714. doi:https://doi.org/10.1007/s11575-008-0103-z

Weathersby, G. B. (1999). Leadership vs management. Management Review, 88(3), 5-10. 